\title{
ASSAY OF PARACETAMOL SYRUP IN DIFFERENT STORAGE TEMPERATURES BY HIGH PERFORMANCE LIQUID CHROMATOGRAPHY
}

\author{
Dian Maria Ulfa ${ }^{1)}$, Nurul Riski ${ }^{1)}$, Dodi Irwandi ${ }^{1)}$ \\ Jurusan Analisa Farmasi dan Makanan, Politeknik Kesehatan Kemenkes Jakarta II, \\ Jl. Raya Ragunan No 29C. Jakarta Selatan, 12540 \\ E-mail: ulfa.dian@gmail.com
}

Submited: 10 October 2019 ; Accepted: 10 October 2019

https://doi.org/10.36525/sanitas.2019.7

\begin{abstract}
Paracetamol formulated in solution, can be hydrolyzed to p-aminophenol, then can be broken down again into quinone-imin. The decomposition rate of paracetamol increases when the temperature is raised and if it is exposed to light directly. The habit of people in storing drugs after the packaging is opened and will be used again raises concerns about the quality of the drugs contained in the drug. The purpose of this study was to determine the level of paracetamol stored at room temperature and chiller temperature using the High Performance Liquid Chromatography (HPLC) method. The study was conducted by testing the levels of paracetamol syrup on the first day and after being stored for three days. Samples were divided into two groups of storage temperatures, room temperature and chiller temperature. The HPLC system used is the L1 column, the mobile phase water-methanol P mixture (3: 1), the flow rate 1.5 . The average paracetamol levels at day 1 storage at room temperature and chiller temperature were $104.61 \%$ and $102.38 \%$. The average paracetamol levels at day 3 storage at room temperature and chiller temperature were 102, $44 \%$ and $98.81 \%$. Storage of paracetamol syrup at the chiller temperature produces smaller levels than at room temperature. Storage for three days shows a significant decrease in levels both at room temperature or chiller temperature ( $p$ value $<0.05)$.
\end{abstract}

Keywords: Paracetamol, Assay, Hplc

\section{ANALISIS KADAR PARASETAMOL DALAM SEDIAAN SIRUP PADA SUHU PENYIMPANAN YANG BERBEDA SECARA KROMATOGRAFI CAIR KINERJA TINGGI}

\begin{abstract}
ABSTRAK
Parasetamol yang diformulasikan dalam bentuk larutan, dapat terhidrolisis menjadi p-aminofenol, selanjutnya dapat terpecah lagi menjadi quinon-imin. Laju dekomposisi parasetamol meningkat jika temperatur dinaikkan dan jika terkena cahaya secara langsung. Kebiasaan masyarakat dalam hal menyimpan obat setelah kemasan dibuka dan akan dipergunakan kembali menimbulkan kekhawatiran tentang mutu obat yang terkandung dalam obat tersebut. Tujuan penelitian ini adalah penetapan kadar parasetamol yang disimpan pada suhu ruangan dan suhu chiller dengan metode Kromatografi Cair Kinerja Tinggi (KCKT). Penelitian dilakukan dengan menguji kadar sampel sirup parasetamol pada hari pertama dan setelah disimpan selama tiga hari. Sampel dibagi menjadi dua kelompok suhu penyimpanan yaitu suhu ruangan dan suhu chiller. Sistem KCKT yang digunakan yaitu kolom L1, fase gerak campuran air-metanol P $(3: 1)$, laju alir 1,5. Rata-rata kadar parasetamol pada penyimpanan hari ke 1 pada suhu ruang dan suhu chiller secara berurut adalah $104.61 \%$ dan $102.38 \%$. Rata-rata kadar parasetamol pada penyimpanan hari ke 3 pada suhu ruang dan suhu chiller secara berurut adalah 102, $44 \%$ dan 98,81\%. Penyimpanan sirup parasetamol pada suhu chiller menghasilkan kadar yang lebih kecil dibandingkan di suhu ruangan. Penyimpanan selama tiga hari
\end{abstract}


menunjukkan terjadinya penurunan kadar yang signifikan baik pada suhu ruangan ataupun suhu chiller (pvalue $<0.05$ ).

Kata Kunci: Parasetamol, Assay, KCKT

\section{PENDAHULUAN}

Asetaminofen ( parasetamol ) merupakan metabolit fenasetin dengan efek antipiretik yang sama dan telah digunakan sejak tahun 1983. Asetaminofen di Indonesia lebih dikenal dengan nama parasetamol, dan tersedia sebagai obat bebas (1). Parasetamol sebagai obat golongan analgetik-antipiretik yang banyak digunakan oleh masyarakat. Parasetamol dianggap sebagai zat antinyeri yang paling aman. Umumnya obat dalam bentuk cair lebih disukai untuk anak-anak daripada bentuk padat karena mudahnya menelan cairan dan kemudahan dalam pemberian dosis (2).

Parasetamol dalam bentuk sediaan larutan bersifat tidak stabil (3). Parasetamol yang diformulasikan dalam bentuk larutan, meningkatkan kemungkinan terhidrolisis menjadi paminofenol, selanjutnya dapat terpecah lagi menjadi quinon-imin. Laju dekomposisi parasetamol meningkat jika temperature dinaikkan dan jika terkena cahaya secara langsung. Ketidakstabilan parasetamol dalam larutan sangat dipengaruhi oleh $\mathrm{pH}$ larutan telah dideskripsikan dengan jelas (4). Parasetamol dapat mengalami hidrolisis pada suasana asam dan basa. Proses dekomposisi ini minimal pada pada $\mathrm{pH}$ mendekati 6. Pada $\mathrm{pH}$ optimum, waktu paruh hidup produk terdegradasi adalah 21,8 tahun pada suhu $25{ }^{\circ} \mathrm{C}(3)(5)$.

Proses dekomposisi ini dapat terjadi selama penyimpanan obat. Kontrol kualitas ketika obat didistribusikan dan penetapan waktu kadaluwarsa obat sangat diperlukan, selain itu penting untuk memformulasikan obat sedekat mungkin dengan $\mathrm{pH}$ optimumnya untuk memperoleh sediaan yang lebih stabil selama penyimpanan (6).

Kebiasaan masyarakat dalam hal menyimpan obat setelah kemasan dibuka dan akan dipergunakan kembali menimbulkan kekhawatiran tentang mutu obat yang terkandung dalam obat tersebut. Untuk mencegah konsumsi obat yang tidak bermutu, rusak dan kandungannya hilang, perlu dilakukan analisis terhadap mutu pada sediaan obat yang beredar dan telah mengalami masa penyimpanan yang mungkin terpapar cahaya, kelembaban, $\mathrm{pH}$ dan terutama suhu. 
Penelitian sebelumnya tentang stabilitas parasetamol terhadap lama dan suhu penyimpanan telah dilakukan oleh beberapa peneliti. Namun metode penetapan kadar yang dilakukan menggunakan alat spektrofotometri (7) (2) (8). Pada percobaan kali ini, penulis melakukan pengujian terhadap sirup parasetamol yang telah mengalami masa penyimpanan dengan kondisi suhu yang sering dilakukan masyarakat untuk menyimpan obat, yaitu kondisi suhu di dalam lemari pendingin dan kondisi suhu ruangan. Penetapan kadar parasetamol dilakukan dengan metode Kromatografi Cair Kinerja Tinggi (KCKT).

\section{METODE PENELITIAN}

\section{Bahan dan Alat}

Bahan yang digunakan yaitu baku parasetamol BPFI dari Badan POM no. Kontrol 307002 kemurnian 100,16 \%, Metanol Pro analisis dari PT. Merck Tbk, Aquades, Sampel Sirup Parasetamol Merk X dari PT. Y, mengandung parasetamol $120 \mathrm{mg}$ setiap $5 \mathrm{~mL}$ sirup.

Alat yang digunakan adalah Alat Kromatografi Cair Kinerja Tinggi merk Shimadzu,

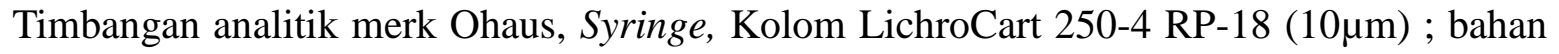
pengisi $\mathrm{L} 1$, panjang $25 \mathrm{~cm}$, diameter $10 \mathrm{~mm}$ ), dan alat-alat gelas

\section{Penetapan Bobot Jenis Sampel}

Gunakan piknometer bersih, kering dan telah dikalibrasi. Timbang sebuah piknometer kosong. Isi piknometer dengan air hingga penuh, lalu timbang pada suhu $25^{\circ}$. Keringkan piknometer tersebut, lalu masukkan sampel hingga penuh dan timbang pada suhu $25^{\circ}$

\section{Pembuatan Fase Gerak}

Buat campuran air-metanol P (3: 1), saring dan awaudarakan. Dicampur metanol P sebanyak $500 \mathrm{~mL}$ dengan $1500 \mathrm{~mL}$ aquades yang telah disaring dengan penyaring berporositas $0,45 \mu \mathrm{m}$ yang dilengkapi dengan pompa vakum ke dalam Erlenmeyer 2000 $\mathrm{mL}$. Disonikasi selama \pm 30 menit untuk menghilangkan gelembung udara dalam larutan. 


\section{Pembuatan Larutan Baku}

Timbang saksama $\pm 10 \mathrm{mg}$ Parasetamol BPFI, masukkan ke dalam labu tentukur 20 $\mathrm{mL}$, larutkan dengan fase gerak sampai tanda. Pipet 1,0 mL larutan ini ke dalam labu tentukur $50 \mathrm{~mL}$, encerkan dengan fase gerak sampai tanda. Saring dengan penyaring berporositas 0,5 $\mu \mathrm{m}$. Gunakan larutan jernih sebagai Larutan Baku.

\section{Pengelompokan Sampel berdasarkan Lama dan Suhu Penyimpanan}

Sampel dibagi menjadi dua kelompok yaitu kelompok sampel yang disimpan pada suhu $31{ }^{\circ} \mathrm{C}$ (suhu ruangan) dan kelompok sampel yang disimpan pada suhu $5-10{ }^{\circ} \mathrm{C}$ (suhu Chiller lemari pendingin). Masing-masing kelompok kemudian dilakukan pengukuran kadar parasetamol pada penyimpanan hari pertama dan hari ketiga.

\section{Pembuatan Larutan uji}

Timbang saksama sejumlah sirup yang telah ditetapkan bobot jenisnya setara dengan lebih kurang $25 \mathrm{mg}$ parasetamol, dimasukkan ke dalam labu tentukur $50 \mathrm{~mL}$. Encerkan dengan fase gerak sampai tanda. Pipet 1,0 mL larutan ini ke dalam labu tentukur $50 \mathrm{~mL}$, encerkan dengan fase gerak hingga tanda. Saring dengan penyaring berporositas 0,5 $\mu \mathrm{m}$. Pengukuran masing-masing sampel dilakukan pengulangan sebanyak 3 kali, kemudian dirata-rata hasilnya.

\section{Sistem kromatografi dan Uji Kesesuaian Sistem (UKS)}

Lakukan seperti yang tertera pada Kromatografi 〈931〉. Kromatografi cair kinerja tinggi dilengkapi dengan kolom dengan detektor $243 \mathrm{~nm}$ dan kolom 3,5 mm x $30 \mathrm{~cm}$ berisi bahan pengisi L1. Laju alir lebih kurang 1,5 mL per menit. Lakukan Uji Kesesuaian Sistem terhadap Larutan baku, rekam respons puncak seperti tertera pada prosedur : efisiensi kolom tidak kurang dari 1000 lempeng teoritis, faktor ikutan tidak lebih dari 2 dan simpangan baku relatif pada penyuntikan ulang tidak lebih dari 2,0\%.

\section{Cara Penetapan}


Suntikkan secara terpisah sejumlah volume sama (lebih kurang $10 \mu \mathrm{L}$ ) Larutan baku dan Larutan uji ke dalam kromatograf, ukur respons puncak utama. Hitung jumlah dalam mg, $\mathrm{C}_{8} \mathrm{H}_{9} \mathrm{NO}_{2}$, dalam tiap $\mathrm{mL}$ larutan oral dengan cara dengan rumus :

$$
50.000\left(\frac{C}{V}\right)\left(\frac{r_{u}}{r_{s}}\right)
$$

$C$ adalah kadar Parasetamol BPFI dalam mg per ml Larutan baku, $V$ adalah volume dalam $\mathrm{ml}$ larutan oral yang digunakan, $r u$ dan $r s$ berturut-turut adalah respons puncak Larutan uji dan Larutan baku (Depkes RI, 1995 : 651)

\section{Uji Statistika}

Hasil rata-rata kadar parasetamol dari kelompok sampel suhu ruangan dan suhu chiller pada hari ketiga dibandingkan menggunakan t-test unequal variance untuk melihat adanya perbedaan yang bermakna. Sebelum dilakukan uji $\mathrm{t}$ data perlu dilakukan uji homogenitas untuk melihat sebaran data apakah terdistribusi normal atau tidak. Dari masing-masing kelompok juga dilakukan uji $\mathrm{t}$ antar data kadar sampel hari pertama dibandingkan dengan hari ketiga untuk sampel yang sama. H0 diterima jika kedua kelompok sampel tidak memiliki perbedaan yang bermakna. H1 diterima jika kedua kelompok sampel memiliki rata-rata kadar yang berbeda bermakna.

\section{HASIL DAN PEMBAHASAN}

Penetapan bobot jenis sampel dilakukan untuk memudahkan konversi bobot penimbangan sampel yang berupa cairan. Bobot jenis suatu zat adalah hasil yang diperoleh dengan membagi bobot zat dengan bobot air dalam piknometer. Kecuali dinyatakan lain dalam monografi, keduanya ditetapkan pada suhu 25² (Depkes RI, 1995 : 1030). Bobot jenis sampel yang diperoleh dari penimbangan adalah $1,045 \mathrm{~g} / \mathrm{mL}$.

Tahapan selanjutnya adalah preparasi sampel sampai sampel siap untuk diukur menggunakan alat KCKT. Sebelum alat KCKT digunakan perlu dilakukan uji kesesuaian sistem untuk memastikan bahwa alat dalam kondisi baik dan bisa digunakan untuk pengujian. Hari yang berbeda perlu dilakukan UKS lagi. Pada pengujian ini dilakukan dua 
kali UKS yaitu sebelum digunakan untuk mengukur kadar sampel yang disimpan pada hari pertama dan UKS setelah disimpan hari ketiga. Hasil uji UKS ditunjukkan pada tabel 1.

Tabel 1. Data Uji Kesesuaian Sitem Sampel

\begin{tabular}{lllll}
\hline Hari & \multicolumn{2}{l}{ Presisi (\% RSD) } & Efisiensi & Faktor Ikutan \\
\cline { 2 - 3 } & Waktu & Luas & Kolom & \\
& Retensi & Area & & \\
\hline Pertama & 0,16 & 0,89 & 1521 & 1 \\
Ketiga & 0,16 & 0,56 & 1,745 & 1,05 \\
\hline
\end{tabular}

*RSD : Relative Standard Deviation

Parameter UKS yang dipersyaratkan dalam monografi ada tiga parameter yaitu presisi, efisiensi kolom dan factor ikutan. Parameter UKS parameter presisi dilakukan terhadap dua data yaitu waktu retensi dan luas area. Hari pertama maupun ketiga parameter presisi memenuhi syarat (RSD < 2). Efisiensi kolom UKS hari pertama dan ketiga juga memenuhi syarat yaitu lebih dari 1000. Parameter faktor ikutan UKS hari pertama dan ketiga juga memenuhi syarat karena tidak lebih dari 2.Berdasarkan data tersebut kondisi alat KCKT yang digunakan adalah baik dan bisa digunakan untuk pengukuran kadar.

Penyiapan sampel dilakukan dengan pelarut yang sama dengan fase gerak. Konsentrasi akhir sampel dan baku dibuat sama yaitu $0.01 \mathrm{mg} / \mathrm{mL}$. Hal ini dilakukan dengan tujuan agar tingkat kesalahan minimal ketika membandingkan luas area baku dan uji. Sampel dan baku perlu dilakukan penyaringan menggunakan penyaring berporositas 0,5 $\mu \mathrm{m}$. Tujuan penyaringan adalah agar sampel yang masuk kedalam kolom KCKT memiliki diameter partikel $<5 \mu \mathrm{m}$. Jika diameternya lebih besar dikhawatirkan terjadi penyumbatan sampel di kolom dan mempersulit proses pembersihan kolom.

Analisis kualitatif dilakukan dengan membandingkan waktu retensi baku dengan sampel. Watu retensi sampel dan baku dapat dilihat pada kromatogram di gambar 2. Waktu retensi baku parasetamol BPFI adalah 2,907 menit, sedangkan waktu retensi sampel adalah 2,89 menit. Dapat disimpulkan sampel benar mengandung parasetamol. 


\section{Baku}

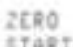

trakt
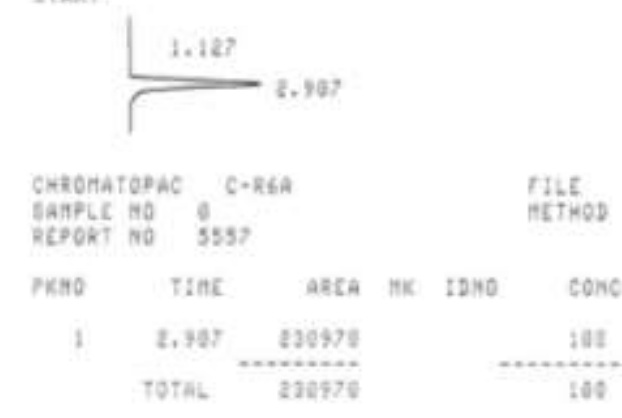

$\operatorname{con} 0$

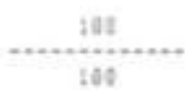

Sampel 1

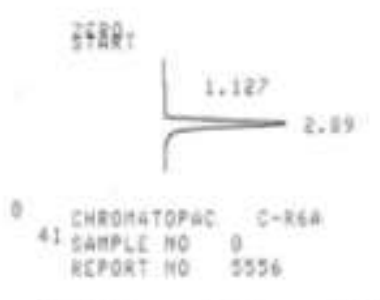

Ne prap

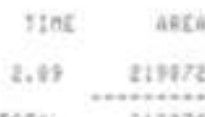

21372

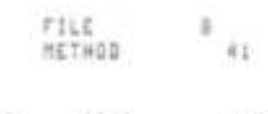

nant

\section{Gambar 1 Kromatogram Baku dan Sampel Parasetamol}

Hasil pengukuran kadar parasetamol dalam sirup untuk kelompok sampel disimpan di suhu ruangan dan chiller pada hari pertama dan ketiga ditunjukkan pada tabel 2.

Tabel 2 Kadar Parasetamol dalam Sirup untuk Kelompok Sampel disimpan pada Suhu Ruangan dan Chillers

\begin{tabular}{lllll}
\hline \multicolumn{2}{c}{ Keterangan } & Luas Area & Kadar (\%) & Kadar Rata-Rata (\%) \\
\hline Suhu Ruangan (A) & Sampel A.1 & 230970 & 103,30 & 104.6133 \\
Hari 1 & Sampel A.2 & 235509 & 105,77 & \\
& Sampel A.3 & 233306 & 104,77 & \\
Suhu Chiller (B) & Sampel B.1 & 230645 & 102,61 & 102.3767 \\
Hari 1 & Sampel B.2 & 230145 & 102,38 & \\
& Sampel B.3 & 229613 & 102,14 & \\
Suhu Ruangan (A) & Sampel A.1 & 233492 & 101,17 & 102.4367 \\
Hari 3 & Sampel A.2 & 237977 & 103,05 & \\
& Sampel A.3 & 237930 & 103,09 & \\
Suhu Chiller (B) & Sampel B.1 & 229196 & 98,74 & 98,81 \\
Hari 3 & Sampel B.2 & 226766 & 99,66 & \\
& Sampel B.3 & 231807 & 98,03 &
\end{tabular}


Persyaran kadar parasetamol sirup dalam monografi farmakope Indonesia edisi ke $\mathrm{V}$ yaitu tidak kurang dari 90,0 \% dan tidak lebih dari 110,0 \% dari jumlah yang tertera pada etiket. Pada tabel 2 dapat dilihat bahwa kadar parasetamol pada hari ke 1 dan setelah penyimpanan pada hari ke 3 memenuhi persyaratan monografi semua baik pada suhu ruangan atau pada suhu chiller.

Perbedaan kadar antara kelompok penyimpanan di suhu ruangan hari ketiga dan suhu chiller pada hari ketiga menunjukkan perbedaan yang signifikan secara statistik (pvalue < 0,05). Penyimpanan pada suhu chiller menghasilkan kadar yang lebih kecil dibandingkan pada suhu ruangan. Perbedaan kadar berdasarkan lama penyimpanan pada suhu ruangan menunjukkan penurunan kadar yang signifikan antara hari pertama dan hari ketiga (pvalue $<0,05$ ). Hari ketiga menunjukkan kadar yang lebih kecil. Begitu juga untuk di suhu chiller menunjukkan hari ke 3 kadar lebih kecil dan perbedaannya signifikan secara statistic (pvalue $<0.05$ ).

\section{SIMPULAN}

Penyimpanan sirup parasetamol pada suhu chiller menghasilkan kadar yang lebih kecil dibandingkan di suhu ruangan. Penyimpanan selama tiga hari menunjukkan terjadinya penurunan kadar yang signifikan baik pada suhu ruangan ataupun suhu chiller.

\section{DAFTAR PUSTAKA}

1. Ganiswara S. Farmakologi dan Terapi. IV. Jakarta: Bagian Farmakologi Fakultas Kedokteran UI; 1995.

2. Rosalina V. Analisis Kadar Sedian Parasetamol Syrup Pada Anak Terhadap Lama Penyimpanan Dan Suhu Penyimpanan. Parapemikir J Ilm Farm. 2018;7(2):283.

3. Koshy KT, Lach JL. Stability of aqueous solutions of N-Acetyl-p-aminophenol. J Pharm Sci. 1961;50(2):113-8.

4. Fairbrother JE. Acetaminophen. Anal Profiles Drug Subst. 1974;3:1-109.

5. Dahn IJR, Van T, Westminster N. Stable liquid paracetamol compositions, and method for preparing same. 1990;2(19):1-7.

6. Connors K, Amidon G, Stella V. Chemical stability of pharmaceuticals: a handbook 
for pharmacists. 1986 [cited $2019 \mathrm{Jul}$ 30]; Available from: https://www.google.com/books?hl=id\&lr=\&id=qw4P5AABgmEC\&oi=fnd\&pg=PA 23\&dq=Connors,+K.A.,+Amidon,+G.L.+and+Stella,+V.J.,+1986.+Chemical+Stabili ty+of+Pharmaceutical.+John+Willey+and+Sons,+NewYork\&ots=7DHPsH7rkw\&si $\mathrm{g}=\mathrm{GQp} 1 w m D D 1 w B S R e 9 h p F N J D i T j k v 8$

7. Zulkarnain I. Stabilitas Kimia Dan Usia Simpan Sirup Parasetamol Pada Berbagai Suhu Penyimpanan. As-Syifa. 2014;06(01).

8. Awalina LK. Uji Stabilitas Dipercepat Sediaan Parasetamol Sirup Dalam Kemasan Botol Polietilen Tereftalat Dengan Metode Spektrofotometri Uv- Vis. Al-ghifari Bandung; 2017. 